\title{
FUNGSI PENDEKATAN BIMBINGAN DAN KONSELING
}

\author{
Warsiati \\ Sekolah tinggi Agama Islam (STAI) Darud Dakwah Wal-Irsyad (DDI), Kota Makassar, \\ Indonesia \\ Email : warsiatiati130200@gmail.com
}

\begin{abstract}
ABSTRAK
Bimbingan dan konseling adalah pelayanan bantuan untuk peserta didik, baik secara perorangan maupun kelompok agar mandiri dan bisa berkembang secara optimal, dalam bimbingan pribadi, sosial, belajar maupun karier melalui berbagai jenis layanan dan kegiatan pendukung berdasarkan norma-norma yang berlaku.
\end{abstract}

\section{Kata kunci : fungsi pendekatan, bimbingan, konseling.}

\section{PENDAHULUAN}

Sebagai salah satu lembaga Pendidikan sekolah membutuhkan pelayanan BK dalam penyelenggaraan dan peningkatan kondisi kehidupan di sekolah demi tercapainya tujuan pendidikan yang berjalan seiring dengan visi profesi konseling yaitu: terwujudnya kehidupan kemanusiaan yang membahagiakan melalui tersedianya pelayanan bantuan dalam memberikan dukungan perkembangan dan pengentasan masalah agar individu berkembang secara optimal, mandiri dan bahagia. ${ }^{1}$

Namun untuk mencapai tujuan tersebut, Konselor haruslah mengetahui apa tujuan dari Bimbingan dan Konseling itu sendiri. Pengetahuan tentang tujuan bimbingan dan konseling itu akan memperlancar pelaksanaan dan lebih menjamin keberhasilan layanan atau kegiatannya, sedangkan pengingkarannya akan dapat menghambat atau bahkan menggagalkan pelaksanaan, serta mengurangi hasil layanan atau kegiatan bimbingan dan konseling itu sendiri. Begitu pula dengan fungsi dari bimbingan dan konseling tidak bisa diabaikan begitu saja, karena fungsi bimbingan dan konseling menguraikan tentang pencegahan, pemahaman,

${ }^{1}$ Adz-Dzaky, Hamdani Bakran, Psikoterapi dan Konseling Islam, (Yogyakarta: Fajar Pustaka Baru, 2001). 
pengembangan, dan lain sebagainya, yang dijadikan sebagai pedoman program pelaksanaan yang harus di ikuti dalam pelaksanaan program pelayanan bimbingan dan konseling. ${ }^{2}$

\section{PEMBAHASAN}

Secara umum fungsi bimbingan dan konseling menurut Prayitno adalah sebagai berikut :

1) Fungsi pemahaman, yaitu pemahaman tentang diri klien beserta permasalahannya oleh klien sendiri ${ }^{3}$

2) Fungsi Pencegahan, yaitu menghindari timbulnya atau meningkatnya kondisi bermasalah pada diri klien,

3) Fungsi pengentasan, yaitu membantu mengeluarkan klien dari masalah yang sedang dihadapinya.

4) Fungsi pemeliharaan dan pengembangan, yaitu memelihara sesuatu yang baik yang ada pada diri individu, baik hal itu merupakan pembawaan ataupun hasil-hasil perkembangan yang telah dicapai selama ini $^{4}$

Adapun beberapa macam pendekatan dalam bimbingan tersebut, diantaranya:

\section{Bimbingan Preventif}

Pendekatan bimbingan ini menolong seseorang sebelum ia menghadapi masalah.

\section{Bimbingan Kuratif atau Korektif}

Dalam pendekatan ini pembimbing menolong seseorang jika ia mengalami masalah yang cukup berat hingga tidak dapat diselesaikan sendiri.

\section{Bimbingan Perseveratif}

Bimbingan ini bertujuan meningkatkan yang sudah baik untuk menjadi lebih baik lagi.

${ }^{2}$ Dahlan, Djawad, Pendidikan dan Konseling di Era Global, (Bandung: Rizqi Press, 2005).

${ }^{3}$ Sainuddin, I. H., \& Wekke, I. S. (2020). Syekh Yusuf Al-Makassari: Pandangan Etika dan Filsafat

${ }^{4}$ Sainuddin, I. H. Dakwah di Era Sosial Media 
Bimbingan dapat dilakukan secara individual dan kelompok, sehingga ada pendekatan individu dan pendekatan kelompok, yaitu:

a) Pendekatan Individu

Pendekatan bimbingan individu dilakukan dengan pendekatan perseorangan. Adapun Pendekatan bimbingan individu mencakup:

1. Informasi individual

2. Penasihatan individual

3. Pengajaran remedial individual

4. Penyuluhan individual

b) Pendekatan Kelompok

Pendekatan bimbingan kelompok diberikan oleh pembimbing perkelompok. Beberapa orang yang bermasalah sama. Dalam Pendekatan bimbingan kelompok mencakup:

1) Informasi kelompok

2) Penasihatan kelompok

3) Pengajaran remedial kelompok

4) Penyuluhan kelompok

5) Home room

6) Sosiodrama

7) Karya wisata

8) Belajar kelompok

9) Kerja kelompok

10) Diskusi kelompok

11) Kegiatan club/pramuka. ${ }^{5}$

${ }^{5}$ Maliki, M. (2015). BIMBINGAN DAN KONSELING DI SEKOLAH DASAR [suatu Pendekatan Imajinatif]. Al-Tazkiah: Jurnal Bimbingan dan Konseling Islam, 4(2), 1-14. 


\section{PENUTUP}

Secara umum fungsi bimbingan dan konseling menurut Prayitno adalah sebagai berikut : Fungsi pemahaman, Fungsi Pencegahan, Fungsi pengentasan, Fungsi pemeliharaan .

Adapun beberapa macam pendekatan dalam bimbingan tersebut, diantaranya:

1. Bimbingan Preventif

2. Bimbingan Kuratif atau Korektif

3. Bimbingan Perseveratif 


\section{DAFTAR PUSTAKA}

Adz-Dzaky, Hamdani Bakran, Psikoterapi dan Konseling Islam, (Yogyakarta: Fajar Pustaka Baru, 2001). http://opac.iainkediri.ac.id

Dahlan, Djawad, Pendidikan dan Konseling di Era Global, (Bandung: Rizqi Press, 2005).

Sainuddin, I. H., \& Wekke, I. S. (2020). Syekh Yusuf Al-Makassari: Pandangan Etika dan Filsafat.

Sainuddin, I. H. Dakwah di Era Sosial Media.

Maliki, M. (2015). BIMBINGAN DAN KONSELING DI SEKOLAH DASAR [suatu Pendekatan Imajinatif]. Al-Tazkiah: Jurnal Bimbingan dan Konseling Islam, 4(2), 1-14. 